\title{
THE DEGREE OF PARTICIPATION IN THE GLOBAL MARKET - A FINANCIAL MARKETS GLOBALISATION CRITERION
}

\author{
Ioana Duca ${ }^{1}$ \\ Ion Pârgaru ${ }^{2}$ \\ Florin Văduva ${ }^{3}$
}

\begin{abstract}
We can measure the globalisation tendency of financial markets by means of several criteria - the degree of financial openness, the degree of financial integration and the degree of participation in the global financial market. This study aims at analysing the degree of participation in the global market as a Financial Markets Globalisation Criterion based on indicators such as the amount of issuing on the international markets, the number of cross listing, the percentage of foreign investments into the GDP etc. We can conclude that although we cannot talk about a global financial market yet, the intensity and extent of the cross-border financial activity indicates an evolution in this direction. Yet, the process does not have a linear trend.
\end{abstract}

Key words: degree of participation in the global financial market, international financial markets, Euromarkets, home bias

JEL Codes: G15

\section{Introduction}

The globalisation of financial markets, namely their integration into a global market is a current trend which must be analysed not separately, but in connection to all the other economic processes occurring at world scale: the increase in interdependences among countries, the international trade dynamics, the expansion of multinational companies, regional integration and the increase in the efforts to institutionalise the financial activities at world level.

We can measure the globalisation tendency of financial markets by means of several criteria, the most relevant of which are: the degree of financial openness, the degree of financial integration and the degree of participation in the global financial market. The degree of financial openness is assessed according to the level of the restrictions operating on a market in connection to the foreign capital flows. Practically, the increase in the degree of financial openness means the foreign investors' access to the national financial markets and the local investors' possibility to make investments abroad.

The degree of financial integration or capital mobility can be analysed by means of the convergence of certain financial equity returns and prices on various markets (price indicators), but also by means of the domestic investment-saving relationship (quantitative indicators). There is a certain dichotomy between the two categories of indicators, the price indicators being suitable for short periods in the analysis, while the quantitative indicators are suitable for longer periods of time (Weidinger-Şoşdean, C., 2005, p. 179).

In this paper we will analyse the indicators of the degree of participation in the global financial market in detail.

\footnotetext{
${ }^{1}$ Titu Maiorescu University, Târgu Jiu

${ }^{2}$ Titu Maiorescu University, Târgu Jiu

${ }^{3}$ Titu Maiorescu University Bucharest, e-mail: florin_văduva@yahoo.com 
The indicators of the degree of participation in the global financial market

The degree of participation in the global financial market refers to the degree of national involvement in the global financial activity. It can be measured by means of:

- the amount of issuing on the international capital markets - Euromarkets. The annual amount of international debt securities issuing on the short, medium and long term (Eurobonds, foreign bonds and long-term bonds, notes and short-term commercial papers) increased from $\$ 53 \mathrm{bn}$ in 1981 (Saini, K. G., 1986, p. 4) to \$2,782.9bn at the end of 2006 (tab. 1), which means a compound average annual growth rate of $17.16 \%$. Regarding the annual issuing of international equity issues, they increased from insignificant levels in the 1980 s to $\$ 82,6 \mathrm{bn}$ in 1996 and $\$ 378.7 \mathrm{bn}$ in 2006 (tab. 2). Although developed countries attract most funds, we notice the return, in the past few years, of developing countries from Latin America to these markets, and also the increase in the participation of other countries with emerging economies, with no consistent history in this area, such as China, Russia, and India etc.

Tabel no. 1

Annual net issues of international debt securities (bn USD), selectively by year

\begin{tabular}{|c|c|c|c|c|c|c|c|c|c|c|}
\hline & 1992 & 1994 & 1996 & 1998 & 2000 & 2002 & 2003 & 2004 & 2005 & 2006 \\
\hline Total of which: & 151.3 & 285.4 & 512.5 & 678.4 & 1241.1 & 1024.1 & 1439.0 & 1613.5 & 1849.2 & 2782.9 \\
\hline Developed countries & 115.3 & 208.4 & 382.4 & 572.9 & 1094.7 & 943 & 1357.5 & 1512.8 & 1681.5 & 2367.3 \\
\hline$\%$ of the total & 76.2 & 73.0 & 74.6 & 84.4 & 88.2 & 92.1 & 94.3 & 93.8 & 90.9 & 85.1 \\
\hline Other countries & 12.8 & 28.7 & 84.7 & 40.2 & 41 & 29.8 & 28.9 & 52.9 & 49.8 & 84.6 \\
\hline$\%$ of the total & 8.5 & 10.1 & 16.5 & 5.9 & 3.3 & 2.9 & 2.0 & 3.3 & 2.7 & 3.0 \\
\hline Off-shore centres & & 38.6 & 19.3 & 10.2 & 82.5 & 29.4 & 29.4 & 24.8 & 86.5 & 320.8 \\
\hline$\%$ of the total & 0 & 13.5 & 3.8 & 1.5 & 6.6 & 2.9 & 2.0 & 1.5 & 4.7 & 11.5 \\
\hline $\begin{array}{l}\text { International } \\
\text { institutions }\end{array}$ & 23.2 & 9.8 & 26 & 55.1 & 22.8 & 21.8 & 23.2 & 23.1 & 31.5 & 10.3 \\
\hline$\%$ of the total & 15.3 & 3.4 & 5.1 & 8.1 & 1.8 & 2.1 & 1.6 & 1.4 & 1.7 & 0.4 \\
\hline
\end{tabular}

Source: BIS Quarterly Review 1997-2007, available at www.bis.org, BIS Annual Report 1997, p. 125 and our own calculations

Tabel no. 2

The international equity issues by nationality of issuer (bn USD), selectively by year

\begin{tabular}{|c|c|c|c|c|c|c|c|c|}
\hline & 1996 & 1998 & 2000 & 2002 & 2003 & 2004 & 2005 & 2006 \\
\hline Total (bn. USD) & 82.6 & 125.5 & 317 & 102.9 & 121.9 & 218.6 & 308.5 & 378.7 \\
\hline $\begin{array}{l}\text { Developed } \\
\text { countries }\end{array}$ & 60.6 & 112.3 & 256.7 & 81.5 & 86 & 159.2 & 213.4 & 229.7 \\
\hline $\begin{array}{l}\text { Percentage of the } \\
\text { total }\end{array}$ & 73.37 & 89.48 & 80.98 & 79.20 & 70.55 & 72.83 & 69.17 & 60.65 \\
\hline Off-shore centres & 7.4 & 4.2 & 14.9 & 4.8 & 4.9 & 12.4 & 17.5 & 24.2 \\
\hline $\begin{array}{l}\text { Percentage of the } \\
\text { total }\end{array}$ & 8.96 & 3.35 & 4.70 & 4.86 & 6.97 & 5.67 & 5.67 & 6.39 \\
\hline $\begin{array}{l}\text { Developing } \\
\text { countries }\end{array}$ & 14.6 & 9.1 & 45.4 & 11.6 & 16.4 & 47.1 & 77.6 & 124.8 \\
\hline $\begin{array}{l}\text { Percentage of the } \\
\text { total, of which: }\end{array}$ & 17.68 & 7.25 & 14.32 & 15.94 & 22.48 & 21.55 & 25.15 & 32.95 \\
\hline China & 2.54 & 0.88 & 6.72 & 5.25 & 7.30 & 8.28 & 8.69 & 13.31 \\
\hline India & 1.57 & 0.08 & 0.28 & 0.29 & 0.41 & 2.10 & 2.79 & 2.67 \\
\hline Russia & 0.97 & 0.00 & 0.13 & 1.26 & 0.49 & 1.14 & 2.11 & 5.18 \\
\hline Brazil & 0.48 & 0.08 & 0.98 & 1.07 & 0.49 & 0.91 & 0.91 & 2.88 \\
\hline
\end{tabular}

calculations 
- the number of cross-listed companies on the international capital markets (on the domestic market and on a foreign one). In these cases, companies are forced to meet the listing requirements on both markets. If the foreign market's requirements cannot be met, there is the alternative of issuing and listing depositary receipts. In general, if listed both on the national and the foreign market, for the foreign market the method of issuing certificates is used. At the end of 2007, a total of 817 depositary receipts issuing were listed on the main stock exchanges, of which 308 on the New York Stock Exchange (most of them issued by companies in China) and 170 on the London Stock Exchange (most of them belonging to companies from Russia). It is estimated that in 2007 approximately a quarter of foreign portfolio investments of equity type made by American investors took the form of such certificates (The Bank of New York Mellon, 2007, p. 7-10).

It must be emphasised that, in the past few years, more and more companies from countries with emerging markets issue such receipts, thus managing to be listed on the large Stock Exchanges in the world: Russia (Gazprom, Lukoil, Unified Energy Systems, Surgutneftegaz), China (Baidu.com, PetroChina, Suntech Power), Brazil (Vale, Petrobras). This tendency, one of the most important in the world, is explained both through the expansion of multinationals companies in these countries and their participation to the international trading and financial circuit, and through their desire to attract important capitals and international visibility. These objectives cannot be achieved locally, due to the poor development of the domestic financial markets.

The dynamics of the total number of foreign companies that are listed on the most important stock exchanges (under the form of shares and receipts) are illustrated in the following table (tab. 3):

Tabel no. 3

The Stock Exchanges with the largest number of listed foreign companies

\begin{tabular}{|c|c|c|c|c|c|c|}
\hline & \multicolumn{2}{|r|}{1995} & \multicolumn{2}{|r|}{2000} & \multicolumn{2}{|r|}{2007} \\
\hline $\begin{array}{l}\text { Stock } \\
\text { Exchange }\end{array}$ & $\begin{array}{l}\text { Number of } \\
\text { listed national } \\
\text { companies }\end{array}$ & $\begin{array}{l}\text { Number of } \\
\text { listed foreign } \\
\text { companies }\end{array}$ & $\begin{array}{l}\text { Number of } \\
\text { listed national } \\
\text { companies }\end{array}$ & $\begin{array}{l}\text { Num } \\
\text { ber of listed } \\
\text { foreign } \\
\text { companies }\end{array}$ & $\begin{array}{l}\text { Number of } \\
\text { listed national } \\
\text { companies }\end{array}$ & $\begin{array}{l}\text { Number of } \\
\text { listed foreign } \\
\text { companies }\end{array}$ \\
\hline Total, of which: & & 3508 & & 2735 & & 3253 \\
\hline $\begin{array}{l}\text { London Stock } \\
\text { Exchange }\end{array}$ & 1971 & 531 & 2428 & 501 & 2588 & 719 \\
\hline NYSE Group & 1996 & 246 & 2035 & 433 & 1852 & 421 \\
\hline NASDAQ & 4766 & 361 & 4239 & 487 & 2762 & 307 \\
\hline $\begin{array}{l}\text { Singapore Stock } \\
\text { Exchange }\end{array}$ & 250 & 22 & & 532 & 472 & 290 \\
\hline $\begin{array}{l}\text { Mexican } \\
\text { Exchange }\end{array}$ & 185 & 0 & 175 & 4 & 125 & 242 \\
\hline $\begin{array}{l}\text { Luxembourg } \\
\text { Exchange }\end{array}$ & 55 & 228 & 54 & 216 & 34 & 227 \\
\hline Euronext & 1213 & 485 & 1416 & 426 & 930 & 225 \\
\hline Deutsche Börse & 678 & 944 & 744 & 245 & 761 & 105 \\
\hline AMEX & 725 & 66 & 643 & 50 & 495 & 104 \\
\hline $\begin{array}{l}\text { Australian Stock } \\
\text { Exchange }\end{array}$ & 1129 & 49 & 1333 & 76 & 1913 & 85 \\
\hline Swiss Exchange & 216 & 233 & 252 & 164 & 257 & 84 \\
\hline
\end{tabular}

Source: processing of World Federation of Exchanges (WFE) statistics www.worldexchanges.org

Since the 1970s, more and more stock exchanges have listed foreign companies, under the form of shares or depositary receipts issuing and the tendency will continue in the following years due to the increase in competition between these entities. In 1975, only 34 foreign companies were listed on the New York Stock Exchange and 129 on the Frankfurt one (Lamy, P., 1995, p. 39). In 
2007, the total number of listed foreign companies was 3,253 (increasing from 2,735 in 2000, but decreasing as compared to 1995), located on 25 stock exchanges, the most important of which were London Stock Exchange, NASDAQ, NYSE, Deutsche Börse, Luxembourg Stock Exchange, Euronext, Swiss Exchange and Singapore Stock Exchange. By analysing the data above, we notice that the London Stock Exchange has the highest degree of internationalisation, with 719 foreign companies listed in December 2007, as compared to 501 at the end of 2000.

Most of them are transacted on the alternative segments (AIM), much less restrictive than the official market. The London Stock Exchange has a long experience in this respect, since in 1970 it listed 387 foreign companies (fig. 1). It can also be seen that the Luxembourg Stock Exchange lists more foreign companies than national ones in all the three years that are analysed.

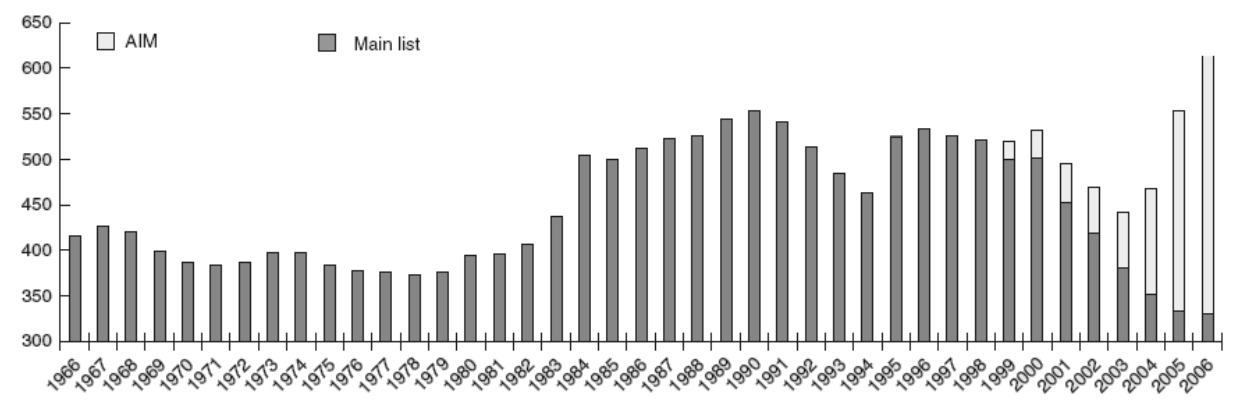

Fig. no.1 - The number of foreign companies listed on the London Stock Exchange in the interval 1966-2006

Source: Information processed from the official London Stock Exchange website www.londonstockexchange.com

The next position is filled by the New York Stock Exchange, which listed 421 foreign companies at the end of 2007, most of which (two thirds) [Our own calculations using the information included in NYSE Facts and Figures, www.nyxdata.com] under the form of ADRs, decreasing as compared to 2000, due to the more severe listing and financial reporting requirements. They led to the withdrawal of certain companies from Great Britain and Latin America (World Bank, 2007, p. 96) ant to the abrupt fall in the number of new companies listed annually. It is also worth noticing EURONEXT, a result of the Amsterdam, Brussels, Paris and Lisbon Stock Exchange merger, for which the figures must be interpreted jointly: 225 foreign companies listed in December 2007, but 201 fewer than in December 2000.

The most important tendency we want to emphasise is that certain exchanges in countries with emerging economies, such as the ones in Mexico and Singapore, have managed in the past seven years to attract a very large number of foreign companies. In 2000, on the Mexican Stock Exchange the shares of only four foreign companies were transacted, but until 2007 their number increased to 242, twice and a half more than the domestic companies.

Another trend is that of the increase in the number of companies from countries with emerging markets listed on the main stock exchanges. Thus, if in 1998 only $13.1 \%$ of the foreign companies listed on the NYSE, NASDAQ, London Stock Exchange and Luxembourg Stock Exchange were from countries with emerging markets, in 2006 their percentage had reached 29.7\% (World Bank, 2007, p. 76).

We must mention here that not all exchanges are permissive of listing foreign securities and we would give as an example here the Japanese Stock Exchanges, which are the least open in this respect. 25 foreign companies were listed on the Tokyo Stock Exchange in 2007, and only one on the Osaka one. The stock exchange activity in Japan can be considered a novel mix of traditional and modern business practices, adapted according to the Anglo-Saxon model. It is expected that in the future the number of listed foreign companies will increase on most markets, especially on 
emerging ones, but we must also emphasise a major obstacle in our opinion - the lack of convergence regarding the IFRS, which hinder the American companies' access to the European capital markets and vice-versa.

- the number of international bonds (foreign bonds and Eurobonds) listed on stock exchanges, illustrated in the following table (tab. 4):

Tabel no. 4

The Stock Exchanges with the largest number of listed international bonds

\begin{tabular}{|c|c|c|c|c|c|c|}
\hline & \multicolumn{2}{|r|}{2000} & \multicolumn{2}{|r|}{2003} & \multicolumn{2}{|r|}{2007} \\
\hline Stock Exchange & $\begin{array}{l}\text { Total listed } \\
\text { bonds }\end{array}$ & $\begin{array}{l}\text { Listed } \\
\text { international } \\
\text { bonds }\end{array}$ & $\begin{array}{c}\text { Total } \\
\text { listed bonds }\end{array}$ & $\begin{array}{l}\text { Listed } \\
\text { international } \\
\text { bonds }\end{array}$ & $\begin{array}{c}\text { Total } \\
\text { listed bonds }\end{array}$ & $\begin{array}{l}\text { Listed } \\
\text { international } \\
\text { bonds }\end{array}$ \\
\hline Total, of which: & & 20,142 & & 30,647 & & 69,658 \\
\hline $\begin{array}{l}\text { Luxembourg } \\
\text { Exchange }\end{array}$ & 13,679 & 12,969 & 21,285 & 20,072 & 31,469 & 31,469 \\
\hline $\begin{array}{l}\text { Irish Stock } \\
\text { Exchange }\end{array}$ & 257 & 111 & 3,716 & 3,175 & 24,385 & $\mathbf{1 7 , 8 1 0}$ \\
\hline $\begin{array}{l}\text { London Stock } \\
\text { Exchange }\end{array}$ & 9,657 & 4,358 & 9,763 & 4,341 & 14,699 & 6,456 \\
\hline Deutsche Börse & 22,522 & 1,300 & 7,000 & 1,019 & 26,031 & 9,182 \\
\hline Euronext & 4096 & 1150 & 3,336 & 864 & 3,173 & 2,829 \\
\hline Swiss Exchange & 1,743 & 782 & 1,261 & 573 & 1,334 & 810 \\
\hline $\begin{array}{l}\text { OMX Nordic } \\
\text { Exchange }\end{array}$ & & & & & 4,826 & 331 \\
\hline Wiener Borse & 1,191 & 12 & 2,571 & 114 & 3,137 & 294 \\
\hline Borsa Italiana & 625 & 41 & 495 & 69 & 548 & 215 \\
\hline NYSE & 1,627 & 208 & 1,256 & 73 & 850 & 88 \\
\hline
\end{tabular}

Source: World Federation of Exchanges (WFE) statistics www.world-exchanges.org, NYSE

Facts and Figures, www.nyxdata.com

Note: OMX Nordic Exchange includes the Stock Exchanges in Copenhagen, Helsinki, Reykjavík, Stockholm, Tallinn, Riga and Vilnius

In 2007, the number of listed international bonds issuing was of $69,658,3.5$ more than in 2000, located on exchanges as Luxembourg Stock Exchange, Irish Stock Exchange, London Stock Exchange, Deutsche Börse, Euronext, Swiss Exchange and OMX Nordic Exchange. In our opinion, this tendency will continue in the following years, especially regarding the Eurobonds, whose requirements are more relaxed and more advantageous than those of other debt securities.

We can notice that most foreign bonds are listed on the European Stock Exchanges (the most important of which is the one in Luxembourg, which listed at the end of 2007 almost half of the bonds issued at international level, especially Eurobonds), the American market being insignificant in this respect. Moreover, if in 2000710 local issuing were also listed, at present there is none, this Stock Exchange becoming one which is dedicated to foreign bonds. This evolution is explained through the lower costs as compared to those of other Stock Exchanges, the effective mechanisms, visibility and experience accumulated in time. If the number of bonds has been decreasing on the New York Stock Exchange in the past few years, on most European Stock Exchanges the situation is quite opposite. The most important evolution is recorded on the Irish Stock Exchange, which reached, in December 2007, the number of 17,810 listed foreign issuing, as compared to only 111 in 2000 . We also notice, on all the European Stock Markets, the much larger number of listed foreign bonds issuing as compared to the number of foreign equities.

- the non-resident investors' participation into the capitals of companies listed on the domestic capital markets, correlated with changing preference for investments on the market of origin. 
In 1970 , only $3.2 \%$ of the shares of the companies transacted on the New York Stock Exchange were owned by non-residents ( $96.8 \%$ by resident investors), which means a strong home-bias, namely a focus on investments into local firms and less diversification on international markets. The preference for local investments was stronger in Europe and Japan as well - in Great Britain the percentage of non-resident ownership was of $6.6 \%$ and in Japan of $4.9 \%$ (tab. 5). In 2000, though, foreign participations in the companies listed on the Great Britain market had reached $32.4 \%$, in France $38.8 \%$, while those on the American market had reached only 7\% (Sabri, N. R., 2002, p. 349-374). In the case of the American markets, the relatively low percentage of foreign shareownership is explained through the intense activity of local (individual and institutional) investors on a dynamic and highly diversified market, which makes the percentage of foreign investors on the market remain low, although the absolute amount of foreign investments in American shares is increasing [From \$243.8bn in 1990, to \$1,115.4bn in 1998 - NYSE Shareownership 2000, p. 33].

Tabel no. 5

The percentage of non-resident shareownership in the companies listed on the domestic markets (selectively)

\begin{tabular}{|c|c|c|c|c|c|c|c|}
\hline & 1970 & 1980 & 1990 & $\begin{array}{ll} & 199 \\
5 & \end{array}$ & $\begin{array}{ll} & 199 \\
8 & \\
\end{array}$ & $\begin{array}{ll} & 200 \\
0 & \\
\end{array}$ & $\begin{array}{ll} & 200 \\
5 & \end{array}$ \\
\hline USA (NYSE) & $3.2 \%$ & $\begin{array}{ll} & 5 \\
\% & \\
\end{array}$ & $6.9 \%$ & $\mathrm{n} / \mathrm{a}$ & $7.2 \%$ & $7 \%$ & $\mathrm{n} / \mathrm{a}$ \\
\hline Japan & $4.9 \%$ & $5.8 \%$ & $4.7 \%$ & $10.5 \%$ & $14.1 \%$ & $18.8 \%$ & $26.7 \%$ \\
\hline France & $\mathrm{n} / \mathrm{a}$ & $\mathrm{n} / \mathrm{a}$ & $\mathrm{n} / \mathrm{a}$ & $24.9 \%$ & $31.9 \%$ & $38.8 \%$ & $39.5 \%$ \\
\hline Germany & $\mathrm{n} / \mathrm{a}$ & $\mathrm{n} / \mathrm{a}$ & $16.6 \%$ & $17.5 \%$ & $15.9 \%$ & $19.9 \%$ & $\%{ }^{21}$ \\
\hline Italy & $\mathrm{n} / \mathrm{a}$ & $\mathrm{n} / \mathrm{a}$ & $\mathrm{n} / \mathrm{a}$ & $11.6 \%$ & $19.6 \%$ & $\begin{array}{ll} & 14 \\
& \\
\end{array}$ & $13.2 \%$ \\
\hline Switzerland & $\mathrm{n} / \mathrm{a}$ & $\mathrm{n} / \mathrm{a}$ & $\mathrm{n} / \mathrm{a}$ & $\mathrm{n} / \mathrm{a}$ & $33.6 \%$ & $\mathrm{n} / \mathrm{a}$ & $37.9 \%$ \\
\hline Great Britain & $6.6 \%$ & $3.6 \%$ & $11.8 \%$ & $16.3 \%$ & $27.6 \%$ & $32.4 \%$ & $32.6 \%$ \\
\hline Norway & $\mathrm{n} / \mathrm{a}$ & $\mathrm{n} / \mathrm{a}$ & $27.2 \%$ & $33.2 \%$ & $31.7 \%$ & $34.1 \%$ & $37.1 \%$ \\
\hline
\end{tabular}

Source: NYSE - Shareownership 2000, p. 34, Japan Shareownership Survey 2007,

Federation of European Securities Exchanges (FESE), February 2007

Regarding the European capital markets, we notice from fig. 2 that the largest foreign shareownership in 2005 is recorded in the case of the companies listed on the Budapest Stock Exchange (77.7\%) and the smallest in the case of those listed on the Milan Stock Exchange $(13.2 \%)$. Both in Hungary and in other countries with emerging markets such as Slovakia, Latvia, Estonia, Lithuania and Poland this situation is explained through the partial performance of the privatisation process through the Stock Exchange, but also through the numerous facilities provided to foreign investors. The home bias has decreased dramatically in the past two years, but despite the benefits from international diversification, many investors, even institutional ones, have a clear preference for the local market (which is called the home bias puzzle in the literature). In our opinion, this is a limit of financial markets globalisation. 


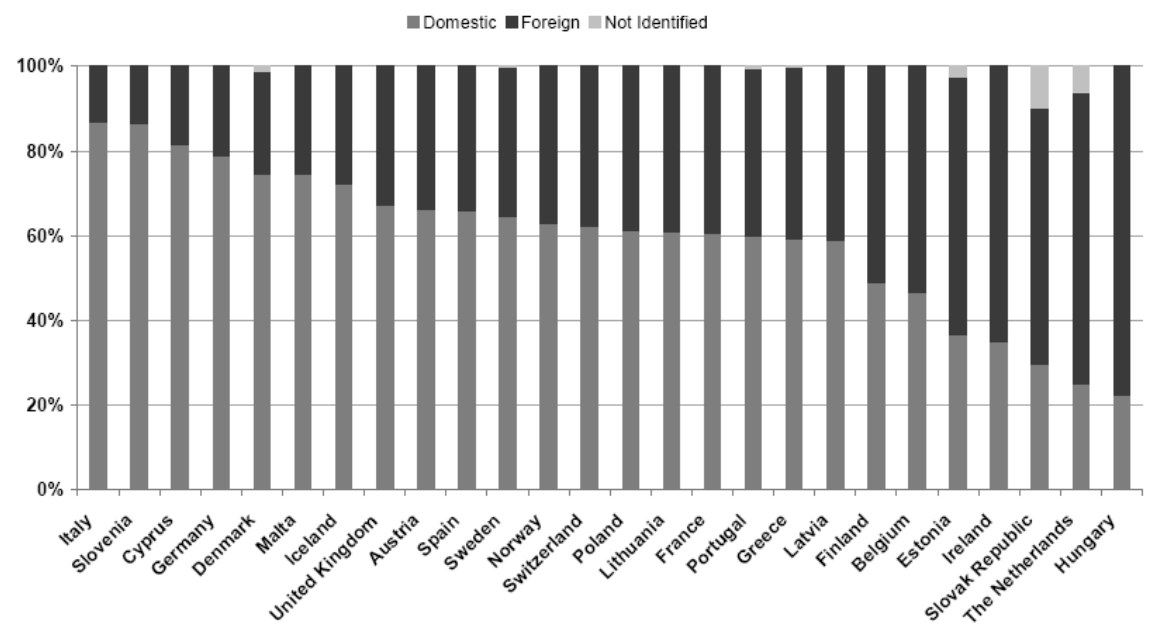

Fig. no. 2 - The Share ownership structure in the companies listed on the European capital markets in 2005

Source: Federation of European Securities Exchanges (FESE) 2007, p. 10

Despite the progress made in the past few years related to transparency and dissemination of the information on international financial markets, the preference for the local assets remains an obvious phenomenon. Recent research shows that this challenges the assumption that investors are aware of the international financial markets' potential to diversify risks. K. R. French and J. M. Poterba explain the home bias through the investors' expectations as to the benefits they might have on foreign markets, suggesting the existence of an exaggerated optimism associated with the local market and a similar pessimism associated with foreign markets (French, K. R., Poterba, J. M., 1991, p. 222-226). Other authors reached the conclusion that there are also other limits to the international diversification of portfolios, such as charging high transaction and information costs on certain markets (Kang, J. K., Stulz, R. M., 1997, p. 3-28), poor corporate governance practices (Kho, B C, Stulz, R M, Warnock, F. E., 2006), certain restrictions that are still operating related to foreign shareownership, currency risk, etc. In our opinion, in the case of institutional investors in certain countries the percent of the foreign assets in the portfolio is also limited by the management policy, especially in the case of pension funds and insurance companies. From tab. 6 we notice that this indicator has high values in the interval 2001-2006 for institutional investors in Holland or Norway (over $70 \%$, respectively over 30\%) and low ones for those in Germany or the United States (5-6\%, respectively 7-9\%).

Tabel. no. 6

The percentage of foreign assets in the portfolio of the institutional investors - OECD countries, selectively

\begin{tabular}{|c|c|c|c|c|c|c|}
\hline Country & 2001 & 2002 & 2003 & 2004 & 2005 & 2006 \\
\hline Canada & 32.71 & 33.72 & 32.46 & 29.69 & 28.72 & 27.68 \\
\hline Germany & 5.15 & 6.40 & 6.37 & 6.68 & 7.35 & 6.64 \\
\hline Holland & 74.97 & 71.93 & 72.53 & 71.67 & 73.48 & 75.23 \\
\hline Norway & 34.17 & 31.40 & 32.16 & 34.76 & 36.84 & 39.35 \\
\hline nd $\quad$ Switzerla & 43.78 & 42.62 & 43.64 & 43.94 & 43.44 & $\mathrm{n} / \mathrm{a}$ \\
\hline USA & 8.75 & 7.14 & 7.69 & 8.24 & 9.32 & 9.53 \\
\hline
\end{tabular}

Source: OCDE statistics, http://stats.oecd.org, NYSE Facts and Figures, www.nyxdata.com and our own calculations 
In fact, several studies have shown in the past few years that we can talk about diminishing the home bias in favour of a regional bias, in terms of the equity portfolios. Analysing the foreign investments portfolio structure in 43 countries, A. García-Herrero and P. Wooldridge showed that most foreign investors tend to invest into their region more that it could be justifiable from the equity markets capitalisation in the region / total equity markets capitalisation ratio, according to the effective international portfolio theory (García-Herrero, A., Wooldridge, P., 2007, p. 57-70).

- the percentage of portfolio foreign investments into the GDP, illustrated in the following table (tab. 7):

Tabel. no. 7

The percentage of portfolio foreign investments flows (inputs an outputs cumulated) in the GDP (\%)

\begin{tabular}{|c|r|r|r|r|r|r|}
\hline Country & $\mathbf{1 9 7 5}$ & $\mathbf{1 9 8 0}$ & $\mathbf{1 9 9 0}$ & $\mathbf{2 0 0 4}$ & $\mathbf{2 0 0 5}$ & $\mathbf{2 0 0 6}$ \\
\hline USA & n/a & 2.2 & 4.2 & 8.78 & 8.37 & 10.99 \\
\hline Japan & 0.8 & 1.8 & 19 & 8.04 & 8.33 & 6.16 \\
\hline Euro zone & - & - & - & 9.92 & 12.02 & 15.91 \\
\hline Canada & 2.4 & 2.7 & 5.2 & 6.13 & 4.58 & 7.70 \\
\hline Great Britain & 5.9 & 7.9 & 32.9 & 19.33 & 23.7 & 27.67 \\
\hline $\begin{array}{c}\text { Emerging markets } \\
\text { (total) }\end{array}$ & - & - & - & 2.81 & & 3.65 \\
\hline
\end{tabular}

Source: Bisignano, J., 1994, IMF 2008, our own statistics and calculations

Compared to the years 1975 and 1980, we notice a significant increase in this indicator in the case of certain developed countries (Great Britain, the Euro zone). We must mention that after the positive evolutions in the interval 1975-1990, since the mid-1990s there has been a decrease in the portfolio investments flows as percentage of the gross domestic product, in the context of the general decrease in financial markets, but the increase was resumed after 2003. In the case of developing countries, this indicator still has low (but increasing) values, which can be explained by the thin portfolio flows into and out of these countries.

\section{Final remarks}

Consequently, after analysing the indicators of the degree of financial engagement we can conclude that, although we cannot talk about a global capital market yet, the intensity and extent of the cross-border financial activity indicates an evolution in this direction. Yet, the process does not have a linear trend and it does not include all the markets, some of them being excluded. Moreover, in certain respects, we notice progress being made, in others there are involutions.

\section{References:}

1. Bisignano, J., 1994. The internationalisation of financial markets: measurements, benefits and unexpected interdependence. Cahiers économiques et monétaires, No. 43, Banque de France.

2. Fabozzi, F., Modigliani, F., Ferri, M., 1994. Foundations of financial markets and institutions. Prentice Halll London.

3. French, K. R., Poterba, J. M., 1991. Investor Diversification and International Equity Markets. American Economic Review, Papers and Proceedings, Vol. 81 (May).

4. García-Herrero, A., Wooldridge, P., 2007. Global and regional financial integration: progress in emerging markets. BIS Quarterly Review.

5. Held, D. et al, 2004. Transformări globale. Politică, economie şi cultură. Iaşi, Editura Polirom.

6. Kang, J. K., Stulz, R. M., 1997. Why is there a home bias? An analysis of foreign portfolio equity ownership in Japan. Journal of Financial Economics, Volume 46, Issue 1, October. 
7. Kho, B C, Stulz, R M, Warnock, F. E., 2006. Financial globalisation, governance and the evolution of the home bias. BIS Working Papers, no 220, December,

8. Lamy, P., 1995. Les bouses de valeurs. Economica, Paris.

9. Sabri, N. R., 2002. Increasing Linkages of Stock Markets and Price Volatility. Research in International Business and Finance, Vol. 16.

10. Saini, K. G., 1986. Capital Market Innovations and Financial Flows to Developing Countries. World Bank Staff Working Papers Number 784. Timişoara.

11. Weidinger-Şoşdean, C., 2005. Euro şi pieţele financiare internaţionale. Ed. Mirton,

12. BIS Quarterly Review 1997-2007, available at www.bis.org, BIS Annual Report 1997.

13. Federation of European Securities Exchanges (FESE) Economics and Statistics Committee (ESC) - Share ownership structure in Europe, February 2007.

14. IMF - Global Financial Stability Report (GFSR), April 2008.

15. Japan Shareownership Survey 2007, www. www.tse.or.jp

16. NYSE Facts and Figures, www.nyxdata.com

17. NYSE - Shareownership 2000, available at www.nyxdata.com

18. OECD statistics, http://stats.oecd.org

19. The Bank of New York Mellon - The Depositary Receipt Markets. The Year in Review $-2007$

20. World Bank - Global Development Finance 2007

21. World Federation of Exchanges (WFE) statistics www.world-exchanges.org 